\title{
The Effects of Almonds on Gut Microbiota, Glycometabolism, and Inflammatory Markers in Patients with Type 2 Diabetes: A Systematic Review and Meta-Analysis of Randomised Controlled Trials
}

\author{
Omorogieva Ojo ${ }^{1, *} \mathbb{D}$, Xiao-Hua Wang ${ }^{2}$, Osarhumwese Osaretin Ojo ${ }^{3}$ \\ and Amanda Rodrigues Amorim Adegboye ${ }^{4}$ \\ 1 Faculty of Education, Health and Human Sciences, School of Health Sciences, University of Greenwich, Avery \\ Hill Campus, Avery Hill Road, London SE9 2UG, UK \\ 2 The School of Nursing, Soochow University, Suzhou 215006, China; wangxiaohua@suda.edu.cn \\ 3 South London and Maudsley NHS Foundation Trust, University Hospital, Lewisham High Street, \\ London SE13 6LH, UK; osarhumwese.ojo@slam.nhs.uk \\ 4 Faculty of Health and Life Sciences, School of Nursing, Midwifery and Health, Coventry University, Priory \\ Street, Coventry CV1 5FB, UK; ad6287@coventry.ac.uk \\ * Correspondence: o.ojo@greenwich.ac.uk
}

check for updates

Citation: Ojo, O.; Wang, X.-H.; Ojo, O.O.; Adegboye, A.R.A. The Effects of Almonds on Gut Microbiota, Glycometabolism, and Inflammatory Markers in Patients with Type 2 Diabetes: A Systematic Review and Meta-Analysis of Randomised Controlled Trials. Nutrients 2021, 13, 3377. https://doi.org/ 10.3390/nu13103377

Academic Editor: Roberto Cangemi

Received: 1 September 2021

Accepted: 23 September 2021

Published: 26 September 2021

Publisher's Note: MDPI stays neutral with regard to jurisdictional claims in published maps and institutional affiliations.

Copyright: (c) 2021 by the authors. Licensee MDPI, Basel, Switzerland. This article is an open access article distributed under the terms and conditions of the Creative Commons Attribution (CC BY) license (https:// creativecommons.org/licenses/by/ $4.0 /)$.
Abstract: The use of nutritional interventions for managing diabetes is one of the effective strategies aimed at reducing the global prevalence of the condition, which is on the rise. Almonds are the most consumed tree nut and they are known to be rich sources of protein, monounsaturated fatty acids, essential minerals, and dietary fibre. Therefore, the aim of this review was to evaluate the effects of almonds on gut microbiota, glycometabolism, and inflammatory parameters in patients with type 2 diabetes. Methods: This systematic review and meta-analysis was carried out according to the preferred reporting items for systematic review and meta-analysis (PRISMA). EBSCOhost, which encompasses the Health Sciences Research Databases; Google Scholar; EMBASE; and the reference lists of articles were searched based on population, intervention, control, outcome, and study (PICOS) framework. Searches were carried out from database inception until 1 August 2021 based on medical subject headings (MesH) and synonyms. The meta-analysis was carried out with the Review Manager (RevMan) 5.3 software. Results: Nine randomised studies were included in the systematic review and eight were used for the meta-analysis. The results would suggest that almond-based diets have significant effects in promoting the growth of short-chain fatty acid (SCFA)producing gut microbiota. Furthermore, the meta-analysis showed that almond-based diets were effective in significantly lowering $(p<0.05)$ glycated haemoglobin $(\mathrm{HbA} 1 \mathrm{c})$ levels and body mass index (BMI) in patients with type 2 diabetes. However, it was also found that the effects of almonds were not significant $(p>0.05)$ in relation to fasting blood glucose, $2 \mathrm{~h}$ postprandial blood glucose, inflammatory markers (C-reactive protein and Tumour necrosis factor $\alpha$, TNF- $\alpha$ ), glucagon-like peptide-1 (GLP-1), homeostatic model assessment of insulin resistance (HOMA-IR), and fasting insulin. The biological mechanisms responsible for the outcomes observed in this review in relation to reduction in $\mathrm{HbA} 1 \mathrm{c}$ and $\mathrm{BMI}$ may be based on the nutrient composition of almonds and the biological effects, including the high fibre content and the low glycaemic index profile. Conclusion: The findings of this systematic review and meta-analysis have shown that almond-based diets may be effective in promoting short-chain fatty acid-producing bacteria and lowering glycated haemoglobin and body mass index in patients with type 2 diabetes compared with control. However, the effects of almonds were not significant $(p>0.05)$ with respect to fasting blood glucose, $2 \mathrm{~h}$ postprandial blood glucose, inflammatory markers (C-reactive protein and TNF- $\alpha$ ), GLP-1, HOMA-IR, and fasting insulin.

Keywords: type 2 diabetes; almonds; tree nuts; glycated haemoglobin; gut microbiota; body mass index 


\section{Introduction}

The use of nutritional interventions is one of the strategies for managing diabetes, which is on the increase worldwide. It is projected that the global prevalence of diabetes could reach 700 million by 2045 , up by $51 \%$ from 463 million who were living with the condition in 2019 [1]. Over $90 \%$ of people with diabetes have type 2 diabetes, which is linked to lifestyle factors [2], and this has implications in terms of morbidity and mortality. Poor diabetes control increases the costs of healthcare as a result of potentially avoidable hospital treatment and drug prescription and in the UK, the total annual spending on patients with type 2 diabetes is expected to rise to about $£ 2.2$ billion by 2040-2050 [3,4]. Therefore, nutritional interventions, which are effective in terms of clinical outcomes, are often recommended for diabetes management [5]. In this regard, the use of nuts, including tree nuts, such as almond, walnut, hazelnut, cashew nuts and Brazil nuts, and groundnuts (mainly peanuts), which are high in unsaturated fatty acids and are rich sources of bioactive nutrients that have significant metabolic and cardiovascular health benefits, have been suggested [6,7].

Almonds are the most consumed tree nut and they are known to be rich sources of protein, monounsaturated fatty acids, essential minerals, and dietary fibre [6,8]. The role of dietary fibre in modulating gut microbiota dysbiosis and in the regulation of glycaemic parameters have been demonstrated in previous systematic reviews and metaanalyses $[9,10]$ and in randomised controlled trials $[11,12]$.

\subsection{Description of the Intervention}

Nuts have been part of the human diet for centuries. Nuts are included in different recipes and, more recently, nuts, particularly almonds, have been consumed as a healthy snack [13]. However, the level of consumption of nuts may vary globally, across different populations. Almonds are tree nuts that have a low glycaemic index, are rich in dietary fibre and unsaturated fatty acids, and have low carbohydrate content [6]. The macro- and micronutrient components of almonds, including monounsaturated fatty acids, polyunsaturated fatty acids, fibre, vitamins, minerals, phytosterols, and polyphenols, have been associated with health benefits including anti-inflammatory and lipid-lowering properties [6,8]. Almonds also have antioxidant properties [8]. The polyphenols and fibre content of almonds may be used as substrates for gut microbial growth and regulation of gut microbiota [8]. It has been suggested that there is an inverse relationship between the consumption of nuts and the risk of developing type 2 diabetes [6].

\subsection{How This Intervention Might Work}

It has been reported that almond consumption increases satiety, decreases postprandial glycaemia, and regulates oxidative stress [6]. Almond consumption may also decrease the rate of nutrient digestion, reduce glucose response, and stimulate incretin and the production of glucagon-like peptide- 1 (GLP-1) [6,14]. The fermentation of the dietary fibre component of almonds may lead to improvement in the composition and metabolic products of gut microbiota, such as an increase in the prevalence of health-promoting bacteria and short-chain fatty acid production, including propionic, butyric, and acetic acid $[10,15,16]$. The short-chain fatty acids produced during this process have been shown to improve glycometabolism in patients with diabetes $[10,15,17]$. An almond-based lowcalorie diet has also been found to be effective in reducing weight [18], which is useful in promoting insulin sensitivity and regulating glycaemic control.

\subsection{Why It Is Important to Do This Review}

Incorporating almonds in well-balanced healthy diets have been shown to confer beneficial effects on glycaemic control in patients with type 2 diabetes $[6,14,19]$. However, it would appear that previous systematic reviews and meta-analyses in this area of research have either focused on the effects of tree nuts in general [20-22], on blood pressure [23], or on fasting blood lipids [24]. For example, Mohammadifard et al. [23], conducted a 
systematic review and meta-analysis on the effect of tree nuts, peanuts, and soy nuts on blood pressure, while Blanco-Mejia et al.'s [20] review focused on the effects of tree nuts on metabolic syndrome. Muley et al. [21], on the other hand, evaluated the effects of tree nuts on glycaemic control in adults with type 2 diabetes, while Musa-Veloso et al. [24] examined the effects of almond consumption on fasting blood lipids. Viguinliouk et al.'s [22] review examined the effect of tree nuts on glycaemic control in patients with diabetes.

However, the present systematic review and meta-analysis will complement the existing literature by providing evidence that focuses on the role of almonds on gut microbiota, glycaemic control, and inflammatory markers. There are indications that increased markers of inflammation and disequilibrium of the gut microbial community are associated with the dysregulation of glycaemic control and type 2 diabetes $[10,25,26]$.

\subsection{Aim}

To evaluate the effects of almonds on gut microbiota, glycometabolism, and inflammatory parameters in patients with type 2 diabetes.

\section{Methods}

This systematic review and meta-analysis was carried out according to the preferred reporting items for systematic review and meta-analysis (PRISMA) [27].

\subsection{Types of Studies}

Only randomised controlled trials (RCTs) including crossover and parallel designs were included in this review.

\subsection{Types of Participants}

Adult participants with type 2 diabetes regardless of the existence of co-morbidities (e.g., obesity) were selected for the review.

\subsection{Types of Interventions}

We included RCTs comparing the provision of almonds or advice to increase almond consumption with a control group (no intervention or habitual diet or other types of nuts) also with type 2 diabetes. There was no restriction regarding the minimum and maximum amount of almonds consumed. RCT including multiple interventions (diet and exercise) were not considered. There was no restriction regarding the duration of the interventions.

\subsection{The Inclusion Criteria}

Randomised controlled trials involving participants with type 2 diabetes and aged 18 years and over were included in this review. Studies with outcomes of interest involving gut microbiota, glycometabolism, anthropometric measurements, and inflammatory parameters were also included in this review.

\subsection{The Exclusion Criteria}

Studies excluded were those with prediabetes; involving other tree nuts other than almonds, such as walnuts; involving patients with gestational diabetes, type 1 diabetes, and only healthy populations. Cluster randomised trials were not eligible for inclusion. Furthermore, studies with participants aged below 18 years and animal studies were excluded from this review. Pregnant and lactating women were not included.

\subsection{Types of Outcome Measures}

The following were the primary outcome measures of interest:

- Gut microbiota;

- Blood glucose parameters: glycated haemoglobin (HbA1c, \%);

- Inflammatory markers: tumour necrosis factor $\alpha(\mathrm{TNF}-\alpha)$; high-sensitivity C-reactive protein (hsCRP); 
- $\quad$ Body mass index (BMI) $\left(\mathrm{Kg} / \mathrm{m}^{2}\right)$.

- Secondary outcome measures of interest:

- $\quad$ Fasting blood glucose (FBG, $\mathrm{mmol} / \mathrm{L}$ );

- Postprandial blood glucose (2 h PBG, $\mathrm{mmol} / \mathrm{L})$;

- Homeostatic model assessment of insulin resistance (HOMA-IR);

- Glucagon-like peptide-1 (GLP-1);

- Fasting insulin.

\subsection{Search Methods for Identification of Studies}

EBSCO-host (which encompasses the Health Sciences Research Databases, including MEDLINE, Academic Search Premier, APA PsycInfo, Psychology and Behavioural Sciences Collection, APA PsycArticles databases, and CINAHL Plus with Full Text), Google Scholar, and EMBASE were the databases searched for relevant articles. In addition, the reference lists of articles were also searched based on the population, intervention, control, outcome, and study (PICOS) framework (Table 1). Searches were carried out from database inception until 1st August 2021. Search terms were drawn from medical subject headings (MesH) and synonyms and were combined using Boolean operators (OR/AND). Two members of the research team (O.O. and O.O.O.) conducted the searches independently and these were cross-checked by the other two members of the team (X.W. and A.R.A.A). Resolution of differences was through discussion and consensus. Search results from databases were exported to EndNote (Analytics, Philadelphia, PA, USA) and de-duplicated.

Table 1. Search terms and search strategy.

\begin{tabular}{|c|c|c|c|c|c|}
\hline Patient/Population & Intervention & Comparator & $\begin{array}{l}\text { Outcome } \\
\text { (Primary) }\end{array}$ & Study Designs & $\begin{array}{l}\text { Combining } \\
\text { Search Terms }\end{array}$ \\
\hline $\begin{array}{l}\text { Patients with } \\
\text { diabetes }\end{array}$ & Almonds & Control & Glycometabolism & $\begin{array}{c}\text { Randomised } \\
\text { controlled trial }\end{array}$ & \\
\hline $\begin{array}{c}\text { Patients with } \\
\text { diabetes OR type } 2 \\
\text { diabetes OR } \\
\text { Diabetes OR } \\
\text { Diabetes } \\
\text { complications OR } \\
\text { diabetes mellitus, } \\
\text { type } 2 \text { OR } \\
\text { diabetes mellitus }\end{array}$ & $\begin{array}{c}\text { Almond OR Tree, } \\
\text { Almond OR } \\
\text { Almond Tree OR } \\
\text { Sweet Almond OR } \\
\text { Almond Trees OR } \\
\text { Tree Nuts OR } \\
\text { Almond, Sweet }\end{array}$ & & & $\begin{array}{l}\text { 1. Randomised } \\
\text { controlled trial OR } \\
\text { controlled clinical } \\
\text { trial OR } \\
\text { randomized OR } \\
\text { placebo OR drug } \\
\text { therapy OR } \\
\text { randomly OR trial } \\
\text { OR groups } \\
\text { 2. "Animals" NOT } \\
\text { "Humans" } \\
\text { 3. } 1 \text { NOT } 2\end{array}$ & $\begin{array}{c}\text { Column } 1 \text { AND } \\
\text { Column } 2 \text { AND } \\
\text { Column } 3\end{array}$ \\
\hline
\end{tabular}

\section{Data Collection and Analysis}

\subsection{Selection of Studies}

The PRISMA flow chart (Figure 1) was based on a set of inclusion and exclusion criteria that were used to select the studies included. 


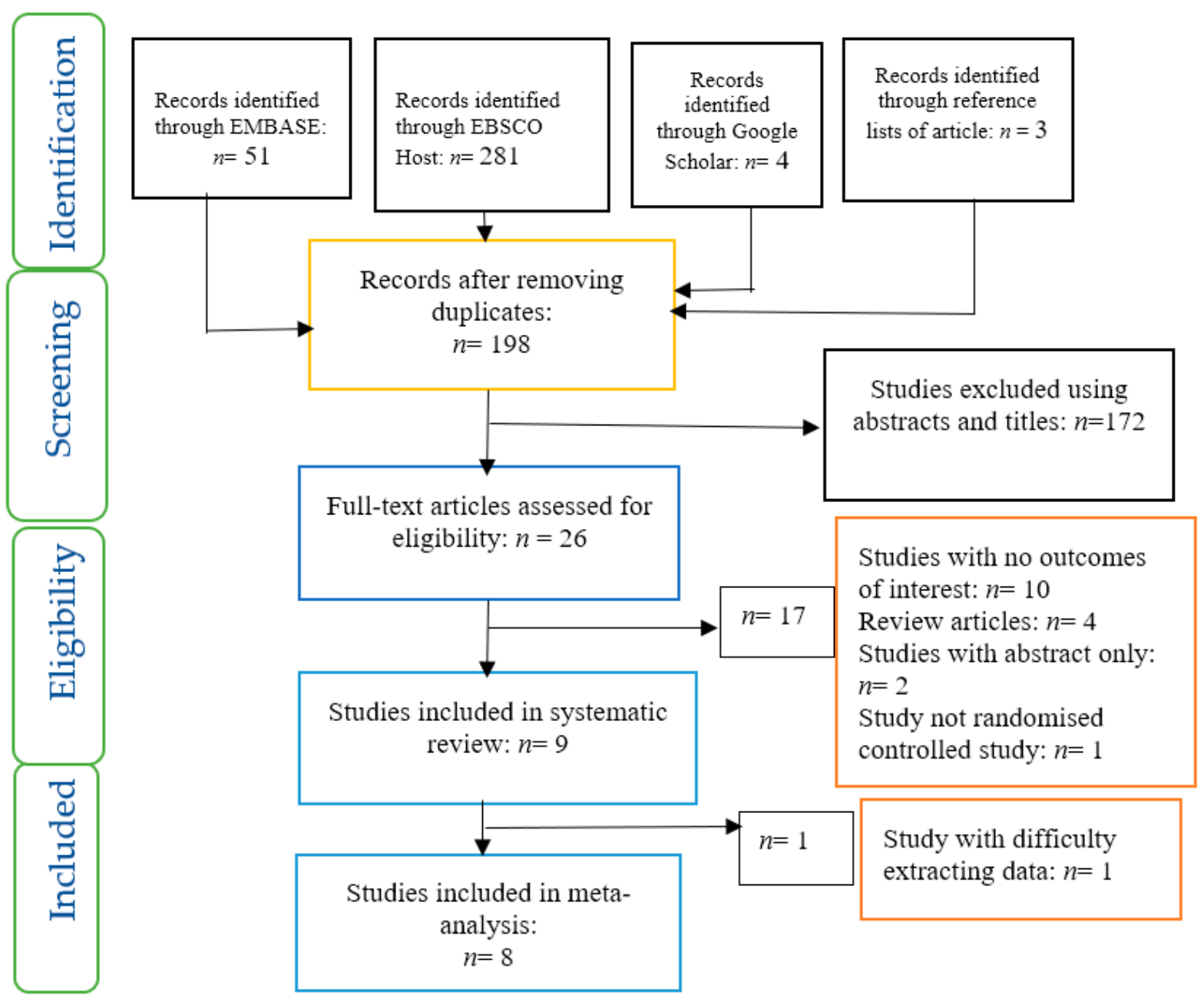

Figure 1. PRISMA flow chart on selection and inclusion of studies.

\subsection{Data Extraction and Management}

The data were extracted in a pre-piloted and standardised form. We extracted the following information: the country where the study was conducted, characteristics of the study population (e.g., mean age), sample size, outcome data, intervention details (duration) (Table 2).

Where the findings of more than one study were reported in one article, only the data from the study pertaining to patients with diabetes were included in the analysis.

The data was extracted by one researcher (O.O.) from the articles included and the three other members of the research team (O.O.O., X.W., A.R.A.A) cross-checked the information. Final values and changes from baseline were used to compare the intervention group with the control group. The units of measurements for some of the parameters were converted to ensure the same unit of measurements for all the studies for that parameter. In studies reporting values in median and 1st and 3rd quartile values, these were converted to means and standard deviations.

\subsection{Assessment of Risk of Bias in Included Studies}

Two members of the research team (O.O. and O.O.O.) evaluated the risk of bias of the included studies using the domain-based risk assessment tool [28]. The results were cross-checked by the other two members of the team (X.W. and A.R.A.A). Allocation concealment, the random sequence generation, blinding of outcome assessment, blinding of participants and personnel, selective reporting, incomplete outcome data, and other biases were the domains evaluated [29]. 
Table 2. General characteristics of included studies.

\begin{tabular}{|c|c|c|c|c|c|c|}
\hline $\begin{array}{l}\text { Citation/Country of } \\
\text { Study }\end{array}$ & Type of Study & $\begin{array}{c}\text { Sample Details and } \\
\text { Duration of Study }\end{array}$ & Mean Age (Years) & Aim & Interventions & Results \\
\hline $\begin{array}{l}\text { Bodnaruc et al. [30] } \\
\text { Canada }\end{array}$ & $\begin{array}{l}\text { A randomised } \\
\text { cross-over study }\end{array}$ & $\begin{array}{c}7 \text { men with type } \\
2 \text { diabetes. } \\
\text { Data were collected } \\
\text { during two experimental } \\
\text { sessions separated by a } \\
\geq 7 \text { day washout period. }\end{array}$ & $63.9 \pm 2.5$ & $\begin{array}{l}\text { To evaluate the effects of } \\
\text { almonds on postprandial } \\
\text { glucose response. }\end{array}$ & $\begin{array}{l}\text { Participants completed } \\
2 \text { experimental visits } \\
\text { and control (white bread, } \\
\text { butter, cheese) and test } \\
\text { (white bread, almonds) } \\
\text { diets were ingested. }\end{array}$ & $\begin{array}{l}\text { The test meal was } \\
\text { associated with lower } \\
\text { postprandial glycemia } \\
\text { and insulinemia. }\end{array}$ \\
\hline $\begin{array}{l}\text { Chen et al. [31] } \\
\text { Taiwan }\end{array}$ & $\begin{array}{l}\text { A randomised cross-over } \\
\text { controlled study }\end{array}$ & $\begin{array}{l}40 \text { patients with type } \\
2 \text { diabetes. } \\
\text { 12-weeks duration. }\end{array}$ & $54.9 \pm 10.5$ & $\begin{array}{l}\text { To examine the effect of } \\
\text { almonds on glycaemia }\end{array}$ & $\begin{array}{l}\text { Approximately } 60 \mathrm{~g} / \text { day } \\
\text { almonds added to a } \\
\text { National Cholesterol } \\
\text { Education Programme } \\
\text { Step II diet (NCEP II) } \\
\text { compared to NCEP II } \\
\text { diet alone as control }\end{array}$ & $\begin{array}{l}\text { Both almond-based and } \\
\text { control diets did not } \\
\text { significantly affect body } \\
\text { weight and BMI or } \\
\text { change HbA1c, fasting } \\
\text { serum glucose, insulin, } \\
\text { or HOMA-IR values. }\end{array}$ \\
\hline $\begin{array}{l}\text { Cohen et al. [32] } \\
\text { USA }\end{array}$ & $\begin{array}{l}\text { A randomised } \\
\text { parallel study }\end{array}$ & $\begin{array}{l}13 \text { participants } \\
\text { diagnosed with type } \\
2 \text { diabetes } \\
\text { Almond-based diets } \\
(n=6) \\
\text { Control }(n=7) \\
\text { 12-weeks duration. }\end{array}$ & $\begin{array}{l}\text { Almond group: } 66 \pm 3.3 \\
\text { Control group: } 66 \pm 3.3\end{array}$ & $\begin{array}{l}\text { To examine the impact of } \\
\text { chronic almond } \\
\text { ingestion on glycaemic } \\
\text { control in patients with } \\
\text { type } 2 \text { diabetes. }\end{array}$ & $\begin{array}{c}\text { Participants were } \\
\text { randomised to almond } \\
\text { group }(1 \mathrm{oz} \text { of almonds, } \\
5 \text { days / week }) \text { or cheese } \\
\text { group ( } 2 \text { cheese sticks, } \\
5 \text { days/week })\end{array}$ & $\begin{array}{l}\text { HbA1c was the only } \\
\text { blood marker that } \\
\text { changed significantly } \\
\text { between the treatment } \\
\text { groups }(p=0.045) . \\
\text { Chronic almond } \\
\text { ingestion resulted in a } \\
4 \% \text { reduction in BMI } \\
\text { compared with control } \\
(p=0.047) .\end{array}$ \\
\hline $\begin{array}{l}\text { Hou et al. [6] } \\
\text { China }\end{array}$ & $\begin{array}{l}\text { A randomised } \\
\text { controlled study }\end{array}$ & $\begin{array}{l}\text { Almond group }(n=14) \\
\text { Peanut group }(n=11) \\
\text { 12-weeks duration. }\end{array}$ & $\begin{array}{c}\text { Almond group: } \\
70.86 \pm 8.21 \\
\text { Peanut group: } 68 \pm 5.80\end{array}$ & $\begin{array}{l}\text { To compare the effects of } \\
\text { peanuts and almonds } \\
\text { incorporated into a } \\
\text { low-carbohydrate diet } \\
\text { on cardiometabolic and } \\
\text { inflammatory } \\
\text { parameters in patients } \\
\text { with type } 2 \text { diabetes }\end{array}$ & $\begin{array}{l}\text { Peanuts or almonds } \\
\text { were incorporated into a } \\
\text { low-carbohydrate diet } \\
\text { and both groups were } \\
\text { compared after a } \\
\text { 3-month intervention. }\end{array}$ & $\begin{array}{l}\text { Almonds and peanuts } \\
\text { have similar effect on } \\
\text { improving fasting and } \\
\text { postprandial blood } \\
\text { glucose among patients } \\
\text { with type } 2 \text { diabetes } \\
\text { when incorporated into a } \\
\text { low-carbohydrate diet. }\end{array}$ \\
\hline
\end{tabular}


Table 2. Cont.

\begin{tabular}{|c|c|c|c|c|c|c|}
\hline $\begin{array}{c}\text { Citation/Country of } \\
\text { Study }\end{array}$ & Type of Study & $\begin{array}{l}\text { Sample Details and } \\
\text { Duration of Study }\end{array}$ & Mean Age (Years) & Aim & Interventions & Results \\
\hline $\begin{array}{l}\text { Li et al. [33] } \\
\text { Taiwan }\end{array}$ & $\begin{array}{l}\text { Randomised cross-over } \\
\text { clinical trial }\end{array}$ & $\begin{array}{c}20 \text { Chinese patients with } \\
\text { type } 2 \text { diabetes. } \\
\text { 12-weeks duration. }\end{array}$ & $58 \pm 2$ & $\begin{array}{l}\text { To evaluate the effect of } \\
\text { almond consumption on } \\
\text { glycaemia in Chinese } \\
\text { patients with type } \\
2 \text { diabetes }\end{array}$ & $\begin{array}{l}\text { Incorporation of almonds } \\
\text { into National Cholesterol } \\
\text { Education Programme Step } \\
\text { II diet (NCEP II) to replace } \\
20 \% \text { of total daily calorie } \\
\text { intake compared with NCEP } \\
\text { II diet alone as control. }\end{array}$ & $\begin{array}{l}\text { Adding almonds into a } \\
\text { healthy diet has } \\
\text { beneficial effects on } \\
\text { adiposity and glycaemic } \\
\text { control. }\end{array}$ \\
\hline $\begin{array}{l}\text { Lovejoy et al. [35] } \\
\text { USA }\end{array}$ & $\begin{array}{c}\text { Randomized } \\
\text { double-blind crossover } \\
\text { design }\end{array}$ & $\begin{array}{c}30 \text { participants with type } \\
2 \text { diabetes. } \\
\text { 16-weeks duration. }\end{array}$ & $53.8 \pm 1.9$ & $\begin{array}{l}\text { To assess the effects of } \\
\text { almond-enriched diets } \\
\text { on insulin sensitivity in } \\
\text { patients with diabetes }\end{array}$ & $\begin{array}{l}\text { The } 4 \text { diets were as follows: } \\
\text { (1) high-fat, high-almond } \\
\text { (HFA; } 37 \% \text { total fat, } 10 \% \\
\text { from almonds); (2) low-fat, } \\
\text { high-almond (LFA; } 25 \% \text { total } \\
\text { fat, } 10 \% \text { from almonds); } \\
\text { (3) high-fat control (HFC; } \\
\text { 37\% total fat, } 10 \% \text { from the } \\
\text { MUFAs from olive or canola } \\
\text { oil); and (4) low-fat control } \\
\text { (LFC; } 25 \% \text { total fat, } 10 \% \\
\text { from olive or canola oil). The } \\
\text { almond-containing diets } \\
\text { provided } 57-113 \text { g } \\
\text { almonds/d depending on } \\
\text { the total energy level }\end{array}$ & $\begin{array}{l}\text { Almond-enriched diets } \\
\text { did not influence } \\
\text { glycaemia in patients } \\
\text { with diabetes. }\end{array}$ \\
\hline
\end{tabular}


Table 2. Cont.

\begin{tabular}{|c|c|c|c|c|c|c|}
\hline $\begin{array}{c}\text { Citation/Country of } \\
\text { Study }\end{array}$ & Type of Study & $\begin{array}{l}\text { Sample Details and } \\
\text { Duration of Study }\end{array}$ & Mean Age (Years) & Aim & Interventions & Results \\
\hline $\begin{array}{l}\text { Ren et al. [14] } \\
\text { China }\end{array}$ & $\begin{array}{l}\text { Randomised controlled } \\
\text { trial }\end{array}$ & $\begin{array}{c}45 \text { participants with type } \\
2 \text { diabetes. } \\
\text { 12-weeks duration. }\end{array}$ & $\begin{array}{l}\text { LCD group: } \\
73.55 \pm 4.99 \\
\text { LFD group: } \\
70.48 \pm 5.91\end{array}$ & $\begin{array}{l}\text { To determine the effect } \\
\text { of almond-based } \\
\text { low-carbohydrate diet } \\
\text { on glycometabolism, gut } \\
\text { microbiota, and GLP-1 in } \\
\text { patients with type } \\
2 \text { diabetes. }\end{array}$ & $\begin{array}{c}\text { The intervention group } \\
\text { consumed a } \\
\text { low-carbohydrate diet, } \\
\text { which included } 56 \mathrm{~g} / \text { day } \\
\text { almonds that replaced } \\
150 \mathrm{~g} / \text { day staple food, while } \\
\text { the control group adopted a } \\
\text { low-fat diet education } \\
\text { programme. }\end{array}$ & $\begin{array}{l}\text { Almond-based LCD may } \\
\text { be effective in regulating } \\
\text { glycometabolism in } \\
\text { patients with diabetes by } \\
\text { stimulating the growth } \\
\text { of SCFA-producing } \\
\text { bacteria, increasing } \\
\text { SCFA production and } \\
\text { promoting GLP-1 } \\
\text { secretion. } \\
\text { The almond-based LCD } \\
\text { significantly increased } \\
\text { the SCFA-producing } \\
\text { bacteria Roseburia, } \\
\text { Ruminococcus, and } \\
\text { Eubacterium. }\end{array}$ \\
\hline $\begin{array}{c}\text { Sweazea et al. [36] } \\
\text { USA }\end{array}$ & $\begin{array}{l}\text { Randomised controlled } \\
\text { study }\end{array}$ & $\begin{array}{l}21 \text { participants with type } \\
2 \text { diabetes. } \\
\text { 12-weeks duration. }\end{array}$ & $\begin{array}{l}\text { Almond group: } \\
57.8 \pm 5.6 \\
\text { Control group: } \\
54.7 \pm 8.9\end{array}$ & $\begin{array}{l}\text { To evaluate if almond } \\
\text { supplementation } \\
\text { without further dietary } \\
\text { advice improves } \\
\text { glycaemic control } \\
\text { compared with control. }\end{array}$ & $\begin{array}{l}\text { The almond group } \\
\text { consumed } 43 \mathrm{~g} \text { almonds } \\
5-7 \text { times per week and to } \\
\text { maintain their usual diet } \\
\text { and activity pattern while } \\
\text { the control group } \\
\text { maintained their usual diet } \\
\text { and activity pattern. }\end{array}$ & $\begin{array}{l}\text { Daily almond } \\
\text { consumption in the } \\
\text { absence of other dietary } \\
\text { or physical activity } \\
\text { activities is useful in } \\
\text { reducing inflammation } \\
\text { in patients with } \\
\text { type } 2 \text { diabetes. }\end{array}$ \\
\hline
\end{tabular}


The risk assessment was conducted using the Review Manager 5.3 software (Copenhagen, Denmark) [28].

\subsection{Data Analysis}

Whenever there were enough trial reporting data on the same outcome, we performed a meta-analysis. Continuous data were analysed as mean difference (MD) with $95 \%$ confidence intervals (CIs), except for the fasting insulin due to differences in the units of measurements of the studies included and, thus, the standardised mean difference (SMD) was used for the meta-analysis. Forest plots were used to depict the results of the metaanalysis and in respect of statistical significance of the overall effect of the intervention, this was set at $p<0.05$.

Sensitivity analysis was also conducted by removing studies one by one from the meta-analysis to assess the level of consistency of the results. The $I^{2}$ statistic expressed as percentage was used to measure the degree of heterogeneity of studies included [29] in the review. A fixed-effects model was used for the meta-analysis for all the parameters of interest except for the fasting insulin due to differences in the units of measurements of the studies included and the standardised mean difference was used for the meta-analysis. Whenever a substantial heterogeneity $(\geq 50 \%)$ was observed and there were enough studies included in the outcome, subgroup analysis was conducted. In addition, final values and changes from baseline were used to compare the intervention group with the control group [29]. If 10 or more studies were included, we would have performed a funnel plot to assess the presence of publication bias and small study effect. The meta-analysis was carried out in Review Manager (RevMan) 5.3 software [28].

\section{Results}

Nine studies were included in the systematic review and eight were used for the meta-analysis (Figure 1). The description and characteristics of eligible studies, including the type of study, details of sample, mean age, the aim of study, interventions, and results are outlined in Table 2. While one study was conducted in Canada [30], three each were conducted in Taiwan $[31,33,34]$ and the USA [32,35,36], and two in China [6,14].

\subsection{Evaluation of the Risk of Bias of Included Studies}

The risk of bias of included studies is shown in Figure 2a,b. All studies showed a low risk of bias in relation to the random sequence generation (selection bias), incomplete outcome data (attrition bias), and selective reporting (reporting bias). However, unclear risk of bias was found in relation to allocation concealment, blinding of participants and personnel, and blinding of outcome assessments in some of the studies [31-34,36].

The presentation of the results of the systematic review and meta-analysis were divided into.

Gut microbiota, glycaemic control, inflammatory parameters, body mass index, homeostatic model assessment of insulin resistance (HOMA-IR), glucagon-like peptide-1 (GLP-1), and fasting insulin.

\subsection{Gut Microbiota}

Only one study [14] examined the effects of almonds on gut microbiota. Ren et al. [14] found that the almond-based low-carbohydrate diet (LCD) significantly increased the shortchain fatty acid (SCFA)-producing bacteria Roseburia, Ruminococcus, and Eubacterium. In particular, the LCD group had a significantly higher population of Roseburia $(p<0.01)$ at the genus level compared with the low-fat diet (LFD) group by the third month, and compared to the baseline, Eubacterium $(p<0.01)$ and Roseburia increased significantly $(p<0.05)$ and Bacteroides $(p<0.05)$ significantly decreased in the almond-based LCD group. 


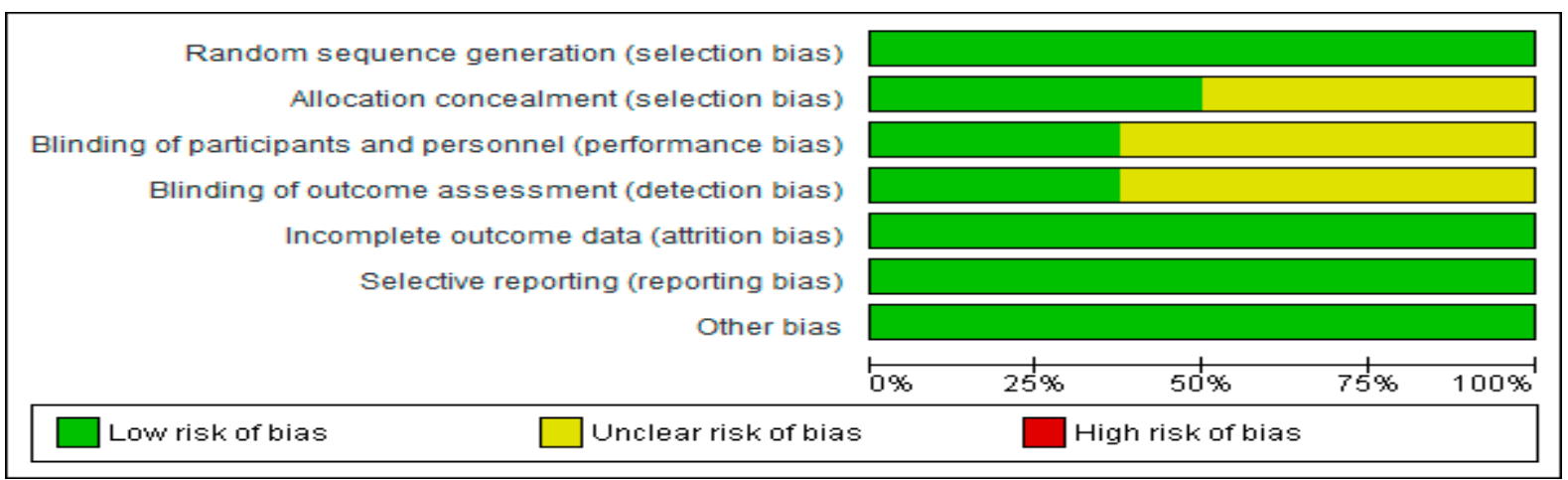

(a)

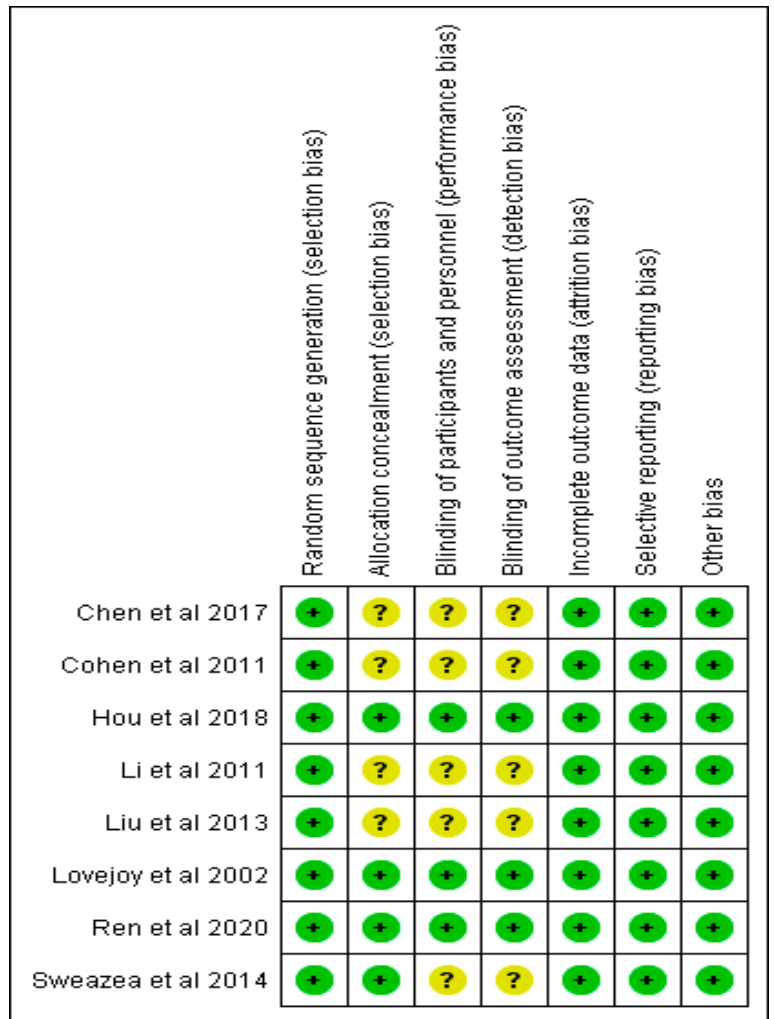

(b)

Figure 2. Shows (a) risk of bias graph and (b) risk of bias summary of studies included.

\subsection{Glycaemic Control}

Chen et al. [31] did not find any significant effect with respect to change in glycated haemoglobin $(\mathrm{HbA} 1 \mathrm{c})$ and fasting serum glucose values in the almond-based and control diets. However, in the study by Cohen et al. [32], there was a significant reduction ( $p=0.045)$ in $\mathrm{HbA} 1 \mathrm{c}$ in the almond-based diet group compared with control group. Ren et al. [14] also showed that almond-based LCD may be effective in modulating glycometabolism in patients with diabetes.

Bodnaruc et al. [30] noted that the almond-based meal was associated with lower postprandial glucose. According to Hou et al. [6], while the almond-based diet did improve fasting, postprandial blood glucose, and glycated haemoglobin in patients with type 2 diabetes, these were not significantly different from the control group. Li et al. [33] observed that including almonds in a healthy diet led to significant improvement $(p<0.05)$ in glycaemic control, while Lovejoy et al. [35] showed that an almond-enriched diet had no significant effect $(p>0.05)$ on glycaemia in patients with diabetes. 
With respect to the meta-analysis, the results of the effects of almonds on glucose control are shown in Figure 3a-d. Six studies each contributed data for the HbA1c analysis (almond group (gp), $n=115$; control gp, $n=114$ ) (Figure 3a; sub-group analysis, Figure 3b) and fasting blood glucose analysis (almond gp, $n=113$; control gp, $n=111$ ) (Figure $3 c$ ). The almond-based diet group experienced a significant reduction $(p<0.001)$ in $\mathrm{HbA} 1 \mathrm{c}$ levels compared to the control group with a mean difference of -0.52 (95\% CI: $-0.58,-0.46)$. Regarding the 2-hour postprandial blood glucose levels, two studies contributed to the data analysis (almond gp, $n=44$; control gp, $n=41$ ) (Figure 3d). The levels of fasting blood glucose and 2-hour postprandial blood glucose were lower in the almond group compared to the control group, although the differences were not significant $(p>0.05)$. The mean differences were -0.03 (95\% CI: $-0.18,0.11)$ for fasting blood glucose and $-0.15(95 \% \mathrm{CI}$ : $-0.44,0.13)$ for postprandial blood glucose.

The sensitivity analysis conducted by removing studies one by one from the metaanalysis did not change the results in relation to $\mathrm{HbA1c}(p<0.05)$, fasting blood glucose $(p>0.05)$, and $2 \mathrm{~h}$ postprandial blood glucose $(p>0.05)$. The sub-group analysis for HbA1c showed that, although there was a significant difference $(p<0.001)$ between the almond group and control with respect to the meta-analysis of the randomised parallel studies, the differences were not significant $(p=0.25)$ in relation to the cross-over studies (Figure $3 b$ ).

\subsection{Inflammatory Markers}

The study by Liu et al. [34] observed that the addition of almonds into a healthy diet could ameliorate inflammation and oxidative stress in patients with type 2 diabetes. Similarly, Sweazea et al. [36] noted that the daily consumption of almonds in the absence of other dietary or physical activity activities could be an effective approach in reducing inflammation in patients with type 2 diabetes.

The meta-analyses of the effects of almonds on inflammatory markers are shown in Figure $4 \mathrm{a}, \mathrm{b}$. Three studies contributed data for the C-reactive protein analysis (almond gp, $n=63$; control gp, $n=63$ ) (Figure 4a) and two studies for tumour necrosis factor- $\alpha$ (TNF- $\alpha$ ) analysis (almond gp, $n=30$; control gp, $n=31$ ) (Figure $4 \mathrm{~b}$ ). The levels of C-reactive protein and TNF- $\alpha$ were lower in the almond group compared to the control group. However, the differences between the two groups were not significant $(p>0.05)$, with mean differences of -0.54 (95\% CI: $-1.61,0.53)$ for C-reactive protein and $-16.67(95 \% \mathrm{CI}:-53.25,19.91)$ for TNF- $\alpha$ respectively. The results did not change between the almond group and control group $(p>0.05)$ with respect to C-reactive protein and TNF- $\alpha$ following sensitivity tests.

\subsection{Body Mass Index (BMI) $\left(\mathrm{Kg} / \mathrm{m}^{2}\right)$}

Chen et al. [31] did not find any significant effect of the almond-based diet with respect to body weight and BMI. In contrast, Cohen et al. [32] found that chronic almond ingestion resulted in a $4 \%$ reduction in BMI compared with control $(p=0.047)$. Six studies contributed to the results of the analysis for BMI (almond gp, $n=105$; control gp, $n=105$ ).

The meta-analysis showed that the BMI was significantly lower $(p<0.05)$ in the almond group compared with the control group (Figure 5), with a mean difference of -0.36 (95\% CI: $-0.52,-0.19)$. The results of the sensitivity analysis showed consistency in terms of the significant difference between the almond group and the control group, except when the Hou et al. [6] study was removed. 


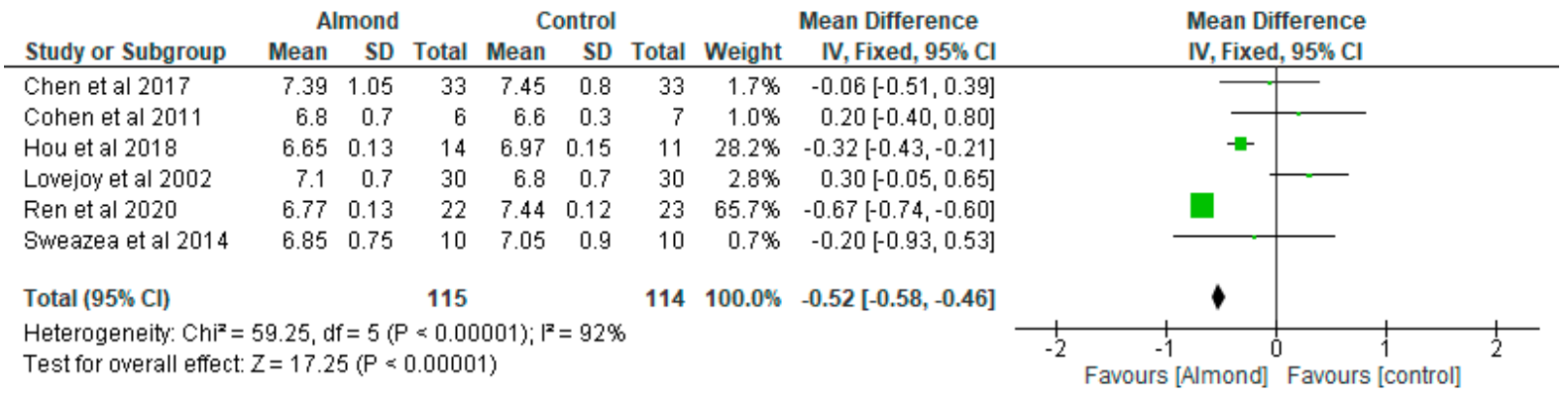

(a)

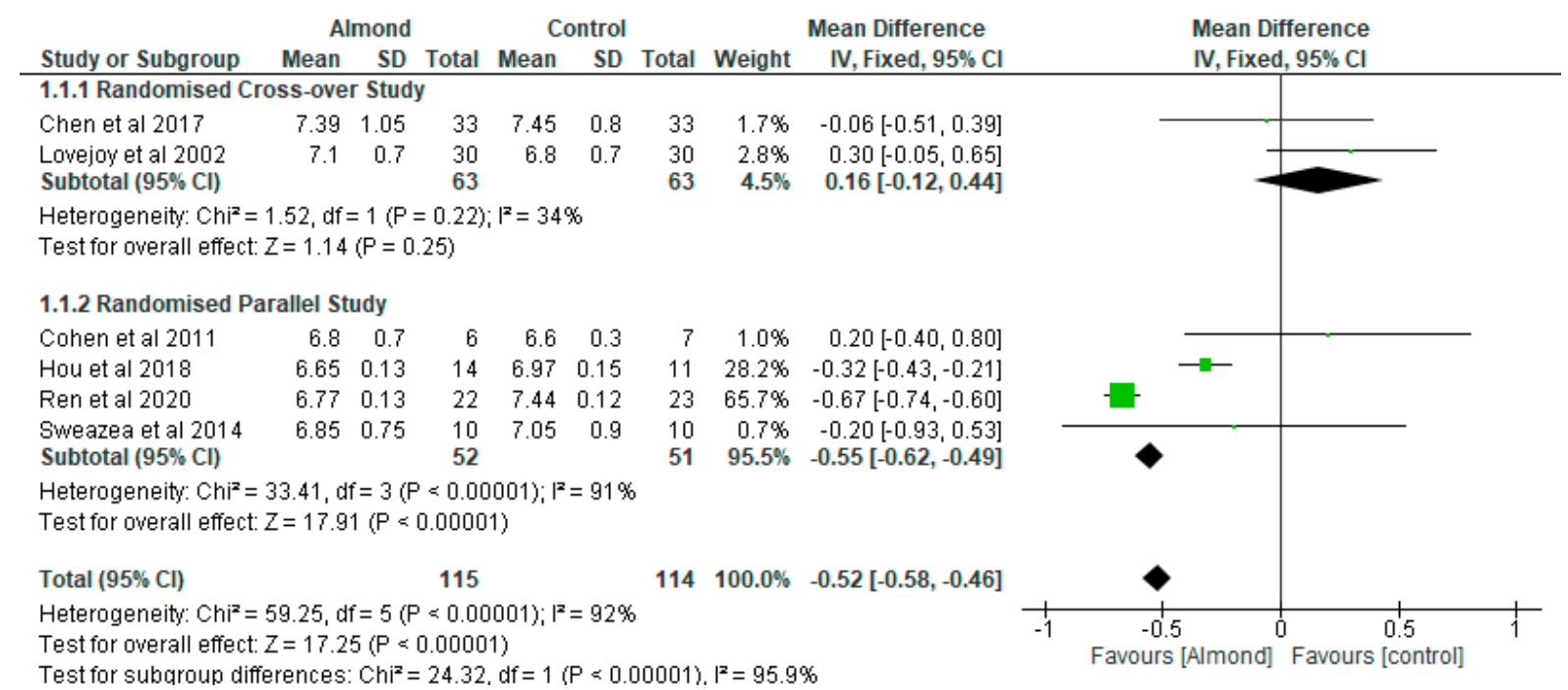

(b)

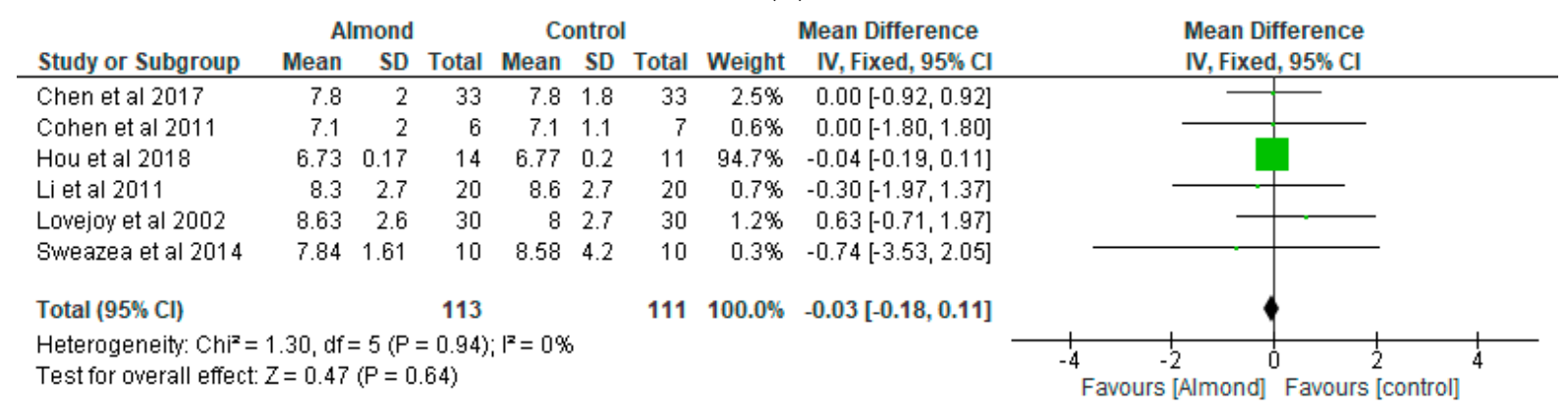

(c)

\begin{tabular}{|c|c|c|c|c|c|c|c|c|c|}
\hline \multirow[b]{2}{*}{ Study or Subgroup } & \multicolumn{3}{|c|}{ Almond } & \multicolumn{3}{|c|}{ Control } & \multicolumn{2}{|r|}{ Mean Difference } & \multirow{2}{*}{$\begin{array}{l}\text { Mean Difference } \\
\text { IV, Fixed, } 95 \% \mathrm{Cl}\end{array}$} \\
\hline & Mean & SD & Total & Mean & SD & Total & Weight & IV, Fixed, $95 \% \mathrm{Cl}$ & \\
\hline Hou et al 2018 & 8.85 & 0.34 & 14 & 9.03 & 0.38 & 11 & $97.8 \%$ & $-0.18[-0.47,0.11]$ & 7 \\
\hline Lovejoy et al 2002 & 15.7 & 3.8 & 30 & 14.6 & 3.8 & 30 & $2.2 \%$ & $1.10[-0.82,3.02]$ & \\
\hline Total $(95 \% \mathrm{Cl})$ & & & 44 & & & 41 & $100.0 \%$ & $-0.15[-0.44,0.13]$ & \\
\hline \multicolumn{10}{|c|}{ 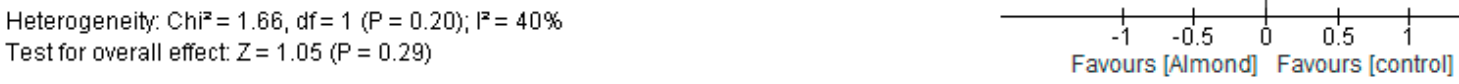 } \\
\hline
\end{tabular}

(d)

Figure 3. The effect of almonds on (a) glycated haemoglobin (Hba1c, \%), (b) Hba1c (\%)—subgroup analysis; (c) fasting blood glucose (mmol/L); (d) $2 \mathrm{~h}$ postprandial blood glucose (mmol/L). 


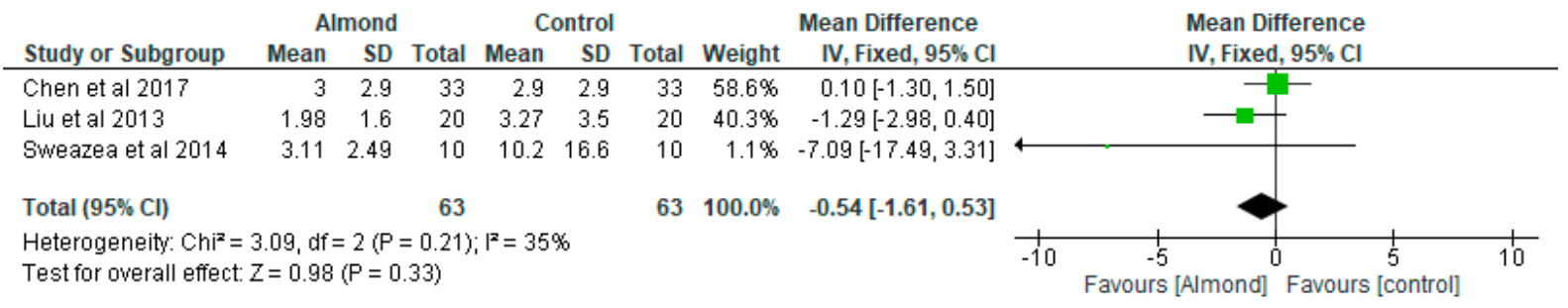

(a)

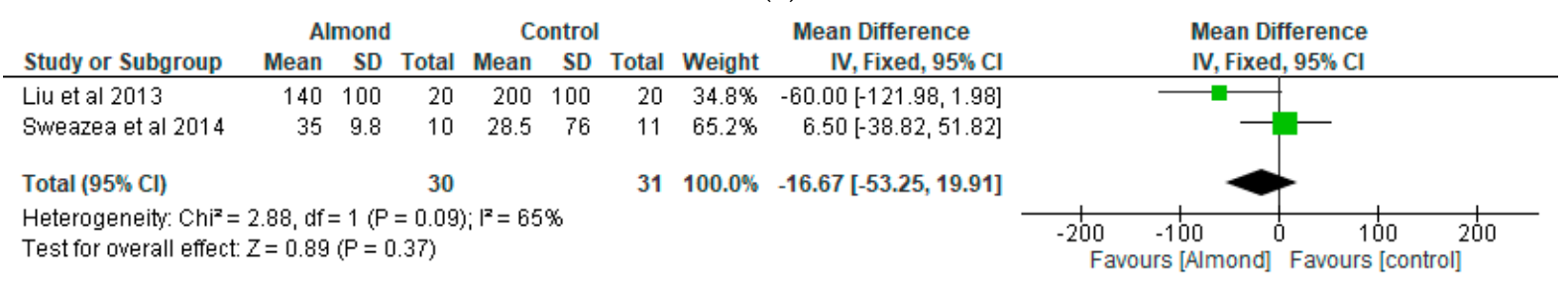

(b)

Figure 4. The effect of almonds on (a) C-reactive protein $(\mathrm{mg} / \mathrm{L})$ and $(\mathbf{b})$ tumour necrosis factor- $\alpha(\mathrm{pg} / \mathrm{mL})$.

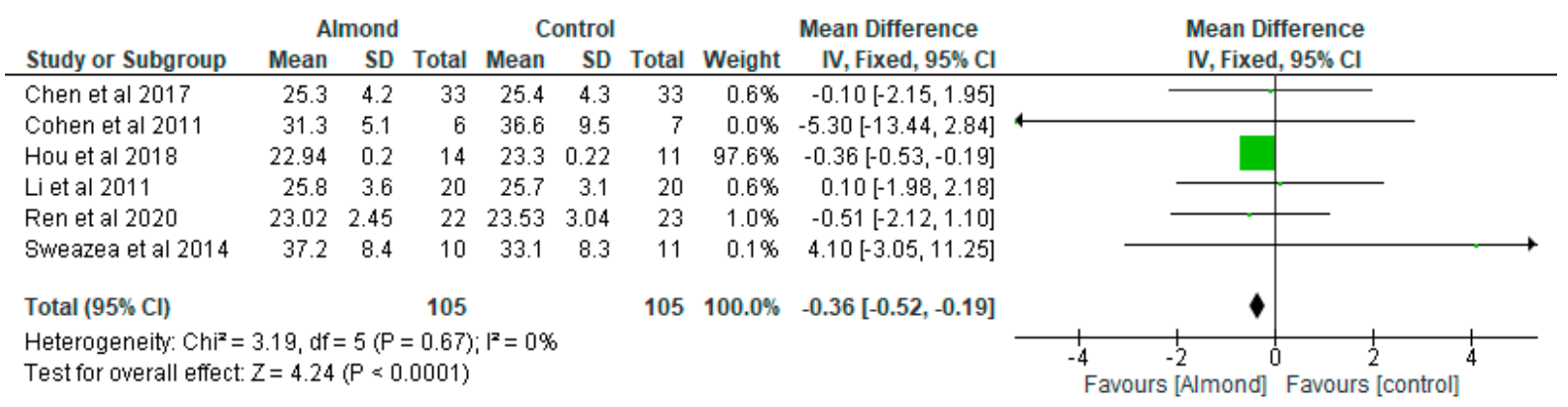

Figure 5. The effect of almonds on body mass index $\left(\mathrm{Kg} / \mathrm{m}^{2}\right)$.

\subsection{Homeostatic Model Assessment of Insulin Resistance (HOMA-IR)}

According to Chen et al. [31], the almond-based diet did not show a significant effect with respect to HOMA-IR compared with control.

Three studies contributed data for HOMA-IR meta-analysis (almond gp, $n=63$; control gp, $n=63$ ) and the difference between the almond and control groups was not significant $(p>0.05)$ (Figure 6). The mean difference was -0.41 (95\% CI: $-1.32,0.50)$. The sensitivity analysis did not change the results between the almond group and the control group $(p>0.05)$ in respect of HOMA-IR.

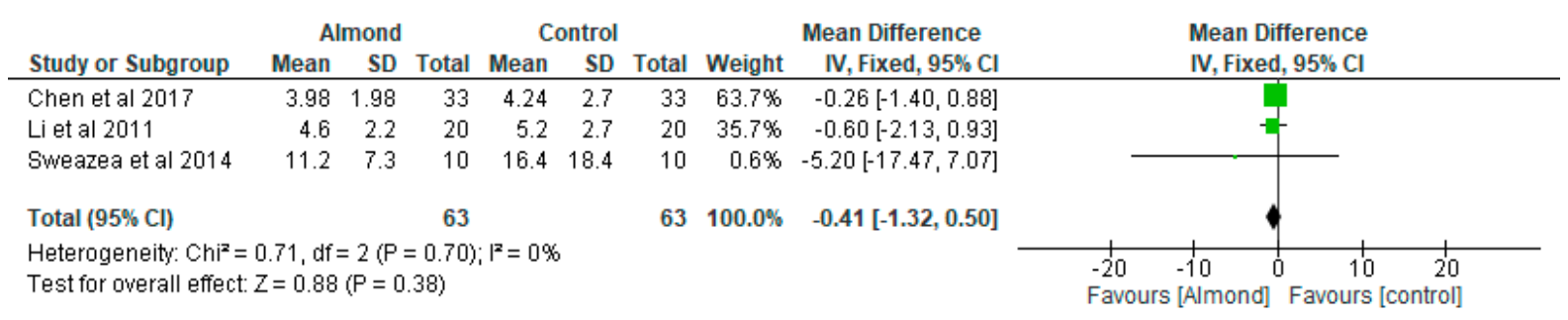

Figure 6. The effect of almond on HOMAR-IR. 


\subsection{Glucagon-Like Peptide-1 (GLP-1)}

There was significant difference $(p<0.05)$ between the almond-based diet group and the control group with respect to the GLP-1 in the study by Ren et al. [14], although Cohen et al. [32] did not find any significant differences $(p>0.05)$ between the two groups.

Regarding the GLP-1 meta-analysis, two studies contributed data (almond gp, $n=28$; control gp, $n=30$ ) (Figure 7). GLP-1 was higher in the almond-based diet group compared with control, although the difference was not statistically significant (mean difference: 0.65 ; $95 \%$ CI: $-0.16,1.47 ; p$-value $=0.12$ ). The sensitivity analysis did not change the results between the almond group and the control group $(p>0.05)$ with to respect to GLP-1.

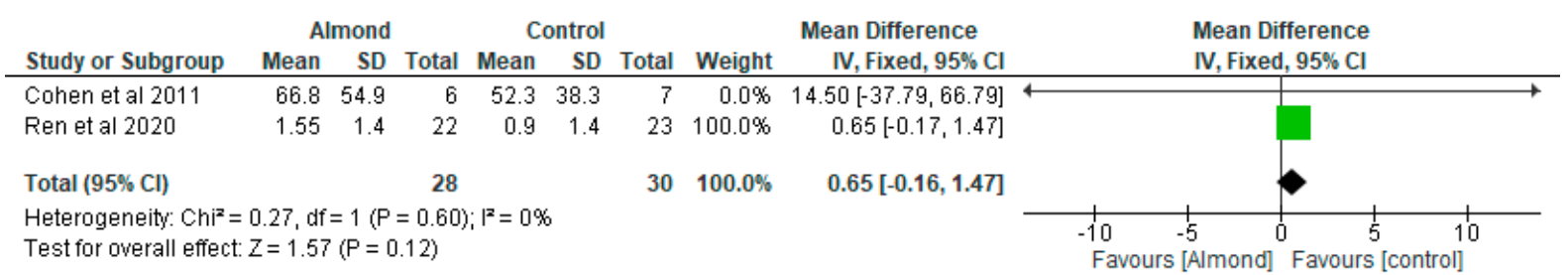

Figure 7. The effect of almond on GLP-1 (pmol/L).

\subsection{Fasting Insulin}

Bodnaruc et al. [30] found that an almond-based diet was associated with lower insulinemia, while Chen et al. [31] did not find any significant effect with respect to insulin levels in the almond-based and control diets. Five studies contributed data for this outcome (almond gp, $n=99$; control gp, $n=100$ ) (Figure 8). It was observed that there was no significant difference between the almond-based group compared to the control group in relation to insulin (standardised mean difference: $-0.12 ; 95 \% \mathrm{CI}:-0.40,0.16$; $p$-value $=0.39)$. There was also no significant difference $(p>0.05)$ between the almond group and the control group following the sensitivity analysis in regards to fasting insulin.

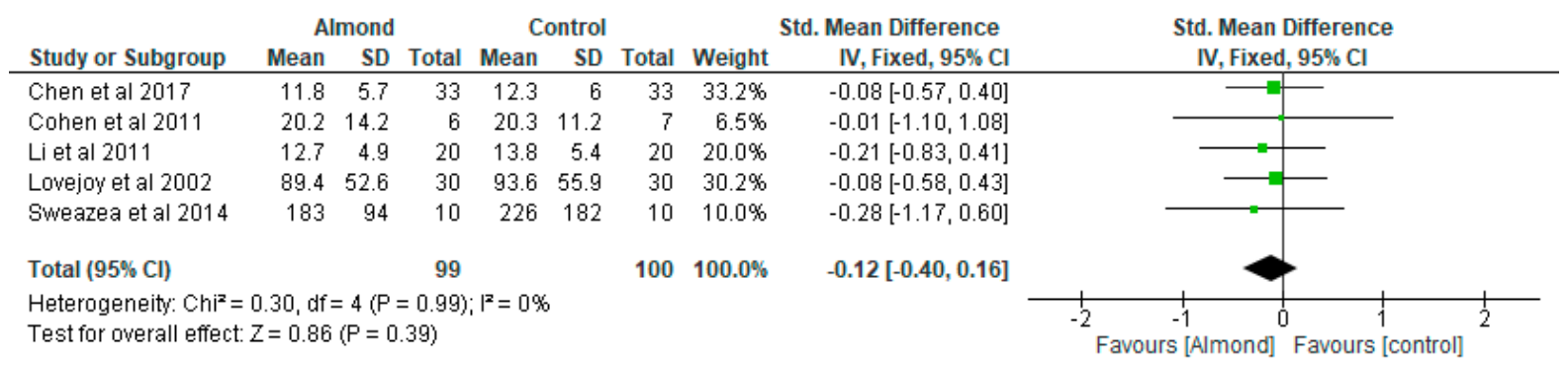

Figure 8. The effect of almond on fasting insulin (standardised mean difference).

\section{Discussion}

The results of the systematic review suggest that almond-based diets can promote the growth of short-chain fatty acid (SCFAs)-producing gut microbiota. Furthermore, the meta-analysis showed that almond-based diets were effective in significantly lowering $(p<0.05)$ glycated haemoglobin and body mass index (BMI) in patients with type 2 diabetes. However, it was also found that the effects of almond-based diets were not significant $(p>0.05)$ in relation to fasting blood glucose, $2 \mathrm{~h}$ postprandial blood glucose, inflammatory markers (C-reactive protein and TNF- $\alpha$ ), GLP-1, HOMA-IR, and fasting insulin.

Our findings of the beneficial effects of almond-based diets on glycated haemoglobin are consistent with a previous study on almond supplementation in patients with type 2 diabetes [19] and an earlier review on the effect of tree nuts on glycaemic control in patients with diabetes [22]. Similarly, our results in relation to BMI are consistent with the findings of a previous study on the effect of almond consumption in the general population [18] and an earlier review of the effect of almonds on BMI [37]. 
The biological mechanisms responsible for the outcomes observed in this review in relation to reduction in glycated haemoglobin and BMI may be based on the nutrient composition of almond and its biological effects [37]. When compared to other nuts, it has been reported that almonds have the highest levels of fibre, monounsaturated and polyunsaturated fats, flavonoids, phytosterols, and phenolic acids [5,37]. Almonds also have a low glycaemic index [5] and almond-based diets have been shown to modulate gut microbiota dysbiosis and promote the production of GLP-1 in patients with type 2 diabetes [14].

The glycaemic index (GI) of food is an important measure of the quality of the food and it is a reflection of the digestibility of the available carbohydrates in the food compared with the reference food, often glucose [38]. It is a measure that ranks food based on the blood glucose response that they produce when ingested compared with the response to glucose or white wheat bread, which are reference foods [39]. Therefore, foods with low GI, such as almonds, usually breakdown slowly during digestion, and are slowly assimilated and, thus, have a slower impact on blood glucose levels and insulin response [40-42]. In a previous systematic review and meta-analysis, Ojo et al. [40], found that diets with low GI were more effective in improving glycated haemoglobin and fasting blood glucose compared with high-GI diets in patients with type 2 diabetes. In contrast, diets with high GI have been associated with type 2 diabetes and cardiovascular diseases due to their effect on blood glucose and insulin levels [38].

Due to the gradual entrance of glucose into the blood leading to reduced and more sustained insulin release, low-GI diets are more effective in controlling glycaemia compared with high GI diets [41]. In addition, low GI diets may be effective in increasing insulin sensitivity by reducing fluctuations in blood glucose levels and minimising insulin secretion over the day [41]. Based on the effectiveness of low-GI diets in controlling glycemia in patients with diabetes, the FAO [42] has recommended the use of a glycaemic index of foods along with the information about food composition in clinical applications in patients with diabetes.

Apart from the potential to improve glycaemic control, it has been suggested that diets with low GI may be useful in reducing weight because they produce a low insulin response [43]. This view is based on the lipogenic effect of hyperinsulinaemia [43]. On the other hand, high-GI diets may elicit a higher postprandial insulin response and this may lead to quicker hunger response and overeating through the reduction in metabolic fuels in the body [43]. Increased satiety and reduced voluntary food intake has been proposed as another mechanism through which foods with low GI can reduce weight [43].

Nuts, including almonds, are rich in energy density and high in fat, therefore, the greater fat availability could lead to reduced gastric emptying and increased satiety $[5,14]$.

Another area of interest is the high soluble fibre and unsaturated fatty acid content of almonds [6]. According to Huo et al. [6], unsaturated fatty acids have been reported to promote the movement of glucose receptors to the cell surface and this could enhance insulin sensitivity. The role of polyunsaturated fatty acids on insulin sensitivity may be based on the fatty acid composition of the cell membrane, which relies on the fatty acid composition of the diet and regulates insulin action [44]. Kien et al. [45] suggested that a possible mechanism of dietary fatty acids in reducing the risk of insulin resistance may be due to the presence of a high level of unsaturated fatty acids in the cell membrane that could influence the physical properties, including plasticity, which promotes the movement of glucose receptors to the cell surface. It has also been shown that skeletal muscle insulin resistance due to obesity or dietary fatty acids may result from defective mitochondrial oxidation of fatty acids, which could lead to the accumulation of ceramides that may inhibit insulin signalling [45]. In addition, a high saturated fatty acid level of the membrane phospholipids increases insulin resistance [44].

Haag and Dippenaar [46] noted that the high saturated fat content of the cell membrane may lead to rigid and unresponsive membranes, while membranes that are high in unsaturated fatty acids promote fluidity and responsiveness. Therefore, the polyun- 
saturated content and omega-3/omega-6 ratio in the muscle and fat membranes are of significant importance in the aetiology of insulin resistance [46]. Furthermore, fatty acidderived entities such as long chain acyl-CoA (coenzymes) may impact negatively on insulin mediated glucose transport and disrupt the insulin signalling cascade [46]. These findings were confirmed in randomised controlled trials in overweight individuals conducted by Kahleova et al. [47], who found that fat quantity and quality were related to body weight and body composition, insulin secretion, and insulin resistance.

Unsaturated fatty acids can also promote the efficiency of $\beta$-cell function through their action in stimulating GLP-1 secretion [6]. The findings of this review did reveal that an almond-based diet was effective in promoting the secretion of GLP-1, although this was not significant compared to the control. GLP-1 is a 30-amino-acid agent, which regulates glucose by stimulating insulin after ingesting a meal [32].

High dietary fibre in almonds can also increase gastric distension, viscosity of gastrointestinal tract, and slower absorption of macronutrients, including slowing the absorption of carbohydrates and the level of postprandial blood glucose [6]. High dietary fibre has been reported to promote the growth of SCFAs producing bacteria, increasing the production of SCFAs and promoting GLP-1 secretion [14].

In the study by Zhao et al. [48], it was found that the presence of greater diversity and abundance of fibre-promoting SCFA producers improved glycated haemoglobin levels in patients with type 2 diabetes through the production of glucagon-like peptide- 1 . The dietary fibre undergoes fermentation by colonic microbiota to produce SCFAs, including propionic, acetic, and butyric acid, which have significant effects on host physiology [49]. The SCFAs are useful in regulating the metabolic and immune system of the host as well as in cell proliferation [50]. However, low dietary fibre intake can cause microbiota dysbiosis, reduction in SCFAs production, and lead to the utilisation of less favourable substrates, such as proteins and fat [50,51]. The lipopolysaccharides resulting from the use of a highfat diet can elicit an inflammatory response and contribute to the development of insulin resistance and type 2 diabetes [51].

\section{Limitations}

One of the studies included [32] was a pilot study with a small sample size. Furthermore, the number of studies included in the meta-analyses was eight or smaller in the different parameters. These could affect the broader application of the findings of the review. Therefore, more studies are required to further explore the role of almonds in patients with type 2 diabetes.

\section{Conclusions}

The findings of this systematic review and meta-analysis have shown that almondbased diets may be effective in promoting short-chain fatty acid-producing bacteria, and lowering glycated haemoglobin and body mass index in patients with type 2 diabetes compared with control. However, the effects of almonds were not significant $(p>0.05)$ with respect to fasting blood glucose, $2 \mathrm{~h}$ postprandial blood glucose, inflammatory markers (C-reactive protein and TNF- $\alpha$ ), GLP-1, HOMA-IR, and fasting insulin.

Author Contributions: Conceptualization, O.O. and O.O.O.; methodology, O.O., X.-H.W. and O.O.O.; A.R.A.A.; validation, O.O., X.-H.W., O.O.O. and A.R.A.A.; formal analysis, O.O.; writing-original draft preparation, O.O.; writing-review and editing, O.O., X.-H.W., O.O.O. and A.R.A.A. All authors have read and agreed to the published version of the manuscript.

Funding: This research received no external funding.

Institutional Review Board Statement: Not applicable.

Informed Consent Statement: Not applicable.

Data Availability Statement: Not applicable.

Conflicts of Interest: The authors declare no conflict of interest. 


\section{References}

1. International Diabetes Federation. Promoting Diabetes Care, Prevention and a Cure Worldwide. 2019. Available online: https:/ / sites.pitt.edu/ \{\}super1/Metabolic/IDF5.pdf (accessed on 23 August 2021).

2. National Collaborating Centre for Chronic Conditions (NCCCC). Type 2 Diabetes: National Clinical Guideline for Management in Primary and Secondary Care (Update); Royal College of Physicians: London, UK, 2008.

3. Bagust, A.; Hopkinson, P.K.; Maslove, L.; Currie, C.J. The projected health care burden of Type 2 diabetes in the UK from 2000 to 2060. Diabet. Med. 2002, 19, 1-5. [CrossRef] [PubMed]

4. Diabetes UK (2012) NHS Spending on Diabetes 'to Reach $£ 16.9$ Billion by 2035'. Available online: https:/ / www.diabetes.org.uk/ about_us/news_landing_page/nhs-spending-on-diabetes-to-reach-169-billion-by-2035 (accessed on 29 June 2021).

5. Mori, A.M.; Considine, R.V.; Mattes, R.D. Acute and second-meal effects of almond form in impaired glucose tolerant adults: A randomized crossover trial. Nutr. Metab. 2011, 8, 6-13. [CrossRef] [PubMed]

6. Hou, Y.-Y.; Ojo, O.; Wang, L.-L.; Wang, Q.; Jiang, Q.; Shao, X.-Y.; Wang, X.-H. A Randomized Controlled Trial to Compare the Effect of Peanuts and Almonds on the Cardio-Metabolic and Inflammatory Parameters in Patients with Type 2 Diabetes Mellitus. Nutrients 2018, 10, 1565. [CrossRef]

7. Jenkins, D.J.A.; Kendall, C.W.C.; Lamarche, B.; Banach, M.S.; Srichaikul, K.; Vidgen, E.; Mitchell, S.; Parker, T.; Nishi, S.; Bashyam, B.; et al. Nuts as a replacement for carbohydrates in the diabetic diet: A reanalysis of a randomised controlled trial. Diabetologia 2018, 61, 1734-1747. [CrossRef] [PubMed]

8. Barreca, D.; Nabavi, S.M.; Sureda, A.; Rasekhian, M.; Raciti, R.; Silva, A.S.; Annunziata, G.; Arnone, A.; Tenore, G.C.; Süntar, I.; et al. Almonds ( Prunus Dulcis Mill. D. A. Webb): A Source of Nutrients and Health-Promoting Compounds. Nutrients 2020, 12, 672. [CrossRef]

9. Ojo, O.; Feng, Q.-Q.; Ojo, O.O.; Wang, X.-H. The Role of Dietary Fibre in Modulating Gut Microbiota Dysbiosis in Patients with Type 2 Diabetes: A Systematic Review and Meta-Analysis of Randomised Controlled Trials. Nutrients 2020, 12, 3239. [CrossRef]

10. Ojo, O.; Ojo, O.O.; Zand, N.; Wang, X. The Effect of Dietary Fibre on Gut Microbiota, Lipid Profile, and Inflammatory Markers in Patients with Type 2 Diabetes: A Systematic Review and Meta-Analysis of Randomised Controlled Trials. Nutrients 2021, $13,1805$. [CrossRef]

11. Reimer, R.A.; Wharton, S.; Green, T.J.; Manjoo, P.; Ramay, H.R.; Lyon, M.R.; Gahler, R.J.; Wood, S. Effect of a functional fibre supplement on glycemic control when added to a year-long medically supervised weight management program in adults with type 2 diabetes. Eur. J. Nutr. 2021, 60, 1237-1251. [CrossRef]

12. Birkeland, E.; Gharagozlian, S.; Birkeland, K.I.; Valeur, J.; Måge, I.; Rud, I.; Aas, A.-M. Prebiotic effect of inulin-type fructans on faecal microbiota and short-chain fatty acids in type 2 diabetes: A randomised controlled trial. Eur. J. Nutr. 2020, 59, 3325-3338. [CrossRef]

13. King, J.C.; Blumberg, J.; Ingwersen, L.; Jenab, M.; Tucker, K.L. Tree nuts and peanuts as components of a healthy diet. J. Nutr. 2008, 138, 1736S-1740S. [CrossRef]

14. Ren, M.; Zhang, H.; Qi, J.; Hu, A.; Jiang, Q.; Hou, Y.; Feng, Q.; Ojo, O.; Wang, X. An Almond-Based Low Carbohydrate Diet Improves Depression and Glycometabolism in Patients with Type 2 Diabetes through Modulating Gut Microbiota and GLP-1: A Randomized Controlled Trial. Nutrients 2020, 12, 3036. [CrossRef]

15. Fang, Q.; Hu, J.; Nie, Q.; Nie, S. Effects of polysaccharides on glycometabolism based on gut microbiota alteration. Trends Food Sci. Technol. 2019, 92, 65-70. [CrossRef]

16. Kaoutari, A.E.; Armougom, F.; Gordon, J.I.; Raoult, D.; Henrissat, B. The abundance and variety of carbohydrate-active enzymes in the human gut microbiota. Nat. Rev. Microbiol. 2013, 11, 497-504. [CrossRef]

17. Nie, Q.; Chen, H.; Hu, J.; Fan, S.; Nie, S. Dietary compounds and traditional Chinese medicine ameliorate type 2 diabetes by modulating gut microbiota. Crit. Rev. Food Sci. Nutr. 2019, 59, 848-863. [CrossRef]

18. Wien, M.A.; Sabate, J.M.; Ikle, D.N.; Cole, S.E.; Kandeel, F.R. Almonds vs complex carbohydrates in a weight reduction program. Int. J. Obes. Relat. Metab. Disord. 2003, 27, 1365. [CrossRef] [PubMed]

19. Gulati, S.; Misra, A.; Pandey, R. Effect of Almond Supplementation on Glycemia and Cardiovascular Risk Factors in Asian Indians in North India with Type 2 Diabetes Mellitus: A 24-Week Study. Metab. Syndr. Relat. Disord. 2017, 15, 98-105. [CrossRef] [PubMed]

20. Blanco Mejia, S.; Kendall, C.W.C.; Viguiliouk, E.; Augustin, L.S.; Ha, V.; Cozma, A.I.; Mirrahimi, A.; Maroleanu, A.; Chiavaroli, L.; Leiter, L.A.; et al. Effect of tree nuts on metabolic syndrome criteria: A systematic review and meta-analysis of randomised controlled trials. BMJ Open 2014, 4, e004660. [CrossRef] [PubMed]

21. Muley, A.; Fernandez, R.; Ellwood, L.; Muley, P.; Shah, M. Effect of tree nuts on glycemic outcomes in adults with type 2 diabetes mellitus: A systematic review. JBI Evid. Synth. 2021, 19, 966-1002. [CrossRef] [PubMed]

22. Viguiliouk, E.; Kendall, C.W.C.; Blanco Mejia, S.; Cozma, A.I.; Ha, V.; Mirrahimi, A.; Jayalath, V.H.; Augustin, L.S.A.; Chiavaroli, L.; Leiter, L.A.; et al. Effect of Tree Nuts on Glycemic Control in Diabetes: A Systematic Review and Meta-Analysis of Randomized Controlled Dietary Trials. PLoS ONE 2014, 9, e0103376. [CrossRef] [PubMed]

23. Mohammadifard, N.; Salehi-Abargouei, A.; Salas-Salvadó, J.; Guasch-Ferré, M.; Humphries, K.; Sarrafzadegan, N. The effect of tree nut, peanut, and soy nut consumption on blood pressure: A systematic review and meta-analysis of randomized controlled clinical trials. Am. J. Clin. Nutr. 2015, 101, 966-982. [CrossRef] 
24. Musa-Veloso, K.; Paulionis, L.; Poon, T.; Lee, H.Y. The effects of almond consumption on fasting blood lipid levels: A systematic review and meta-analysis of randomised controlled trials. J. Nutr. Sci. 2016, 5, e34. [CrossRef] [PubMed]

25. Tsai, Y.-L.; Lin, T.-L.; Chang, C.-J.; Wu, T.-R.; Lai, W.-F.; Lu, C.-C.; Lai, H.-C. Probiotics, prebiotics and amelioration of diseases. J. Biomed. Sci. 2019, 26, 3. [CrossRef] [PubMed]

26. Carrera-Quintanar, L.; López Roa, R.I.; Quintero-Fabián, S.; Sánchez-Sánchez, M.A.; Vizmanos, B.; Ortuño-Sahagún, D. Phytochemicals that influence gut microbiota as prophylactics and for the treatment of obesity and inflammatory diseases. Mediat. Inflamm. 2018, 2018, 9734845. [CrossRef] [PubMed]

27. Moher, D.; Liberati, A.; Tetzlaff, J.; Altman, D.G. The PRISMA Group. Preferred reporting items for systematic reviews and meta-analyses: The PRISMA statement. Ann. Intern. Med. 2009, 151, 264-269. [CrossRef]

28. The Nordic Cochrane Centre. Review Manager, Version 5.3; The Nordic Cochrane Centre; The Cochrane Collaboration: Copenhagen, Denmark, 2014.

29. Higgins, J.P.T.; Green, S. Cochrane Handbook for Systematic Reviews of Interventions; Wiley-Blackwell: Hoboken, NJ, USA, 2009.

30. Bodnaruc, A.M.; Prud'homme, D.; Giroux, I. Acute effects of an isocaloric macronutrient-matched breakfast meal containing almonds on glycemic, hormonal, and appetite responses in men with type 2 diabetes: A randomized crossover study. Appl. Physiol. Nutr. Metab. 2020, 45, 520-529. [CrossRef]

31. Chen, C.-M.; Liu, J.-F.; Li, S.-C.; Huang, C.-L.; Hsirh, A.-T.; Weng, S.-F.; Chang, M.-L.; Li, H.-T.; Mohn, E.; Oliver Chen, C.-Y. Almonds ameliorate glycemic control in Chinese patients with better controlled type 2 diabetes: A randomized, crossover, controlled feeding trial. Nutr. Metab. 2017, 14, 1-12. [CrossRef]

32. Cohen, A.E.; Johnston, C.S. Almond ingestion at mealtime reduces postprandial glycemia and chronic ingestion reduces hemoglobin $\mathrm{A}(1 \mathrm{c})$ in individuals with well-controlled type 2 diabetes mellitus. Metab. Clin. Exp. 2011, 60, 1312-1317. [CrossRef]

33. Li, S.-C.; Liu, Y.-H.; Liu, J.-F.; Chang, W.-H.; Chen, C.-M.; Chen, C.-Y.O. Almond consumption improved glycemic control and lipid profiles in patients with type 2 diabetes mellitus. Metab. Clin. Exp. 2011, 60, 474-479. [CrossRef]

34. Liu, J.-F.; Liu, Y.-H.; Chen, C.-M.; Chang, W.-H.; Chen, C.-Y. The effect of almonds on inflammation and oxidative stress in Chinese patients with type 2 diabetes mellitus: A randomized crossover controlled feeding trial. Eur. J. Nutr. 2013, 52, 927-935. [CrossRef]

35. Lovejoy, J.C.; Most, M.M.; Lefevre, M.; Greenway, F.L.; Rood, J.C. Effect of diets enriched in almonds on insulin action and serum lipids in adults with normal glucose tolerance or type 2 diabetes. Am. J. Clin. Nutr. 2002, 76, 1000-1006. [CrossRef]

36. Sweazea, K.; Johnston, C.; Ricklefs, K.D.; Petersen, K.N. Almond supplementation in the absence of dietary advice significantly reduces C-reactive protein in subjects with type 2 diabetes. J. Funct. Foods 2014, 10, 252-259. [CrossRef]

37. Dreher, M.L. A Comprehensive Review of Almond Clinical Trials on Weight Measures, Metabolic Health Biomarkers and Outcomes, and the Gut Microbiota. Nutrients 2021, 13, 1968. [CrossRef]

38. Mohan, V.; Anjana, R.M.; Gayathri, R.; Ramya Bai, M.; Lakshmipriya, N.; Ruchi, V.; Sudha, V. Glycemic Index of a Novel High-Fiber White Rice Variety Developed in India-A Randomized Control Trial Study. Diabetes Technol. Ther. 2016, 18, 164-170. [CrossRef]

39. Similä, M.E.; Valsta, L.M.; Kontto, J.P.; Albanes, D.; Virtamo, J. Low-, medium- and high-glycaemic index carbohydrates and risk of type 2 diabetes in men. Br. J. Nutr. 2011, 105, 1258-1264. [CrossRef]

40. Ojo, O.; Ojo, O.O.; Adebowale, F.; Wang, X.-H. The Effect of Dietary Glycaemic Index on Glycaemia in Patients with Type 2 Diabetes: A Systematic Review and Meta-Analysis of Randomized Controlled Trials. Nutrients 2018, 10, 373. [CrossRef] [PubMed]

41. Thomas, D.E.; Elliott, E.J. The use of low-glycaemic index diets in diabetes control. Br. J. Nutr. 2010, 104, 797-802. [CrossRef] [PubMed]

42. Food and Agricultural Organisation (FAO). Carbohydrates in Human Nutrition. Report of a Joint FAO/WHO Expert Consultation; FAO (Food and Nutrition Paper-66); FAO: Rome, Italy, 1998; Available online: http:/ / www.fao.org/docrep/w8079e/w8079e00.htm (accessed on 16 August 2018).

43. Esfahani, A.; Wong, J.W.; Mirrahimi, A.; Villa, C.R.; Kendall, C.C. The application of the glycemic index and glycemic load in weight loss: A review of the clinical evidence. IUBMB Life 2011, 63, 7-13. [CrossRef]

44. Salmerón, J.; Hu, F.B.; Manson, J.E.; Stampfer, M.J.; Colditz, G.A.; Rimm, E.B.; Willett, W.C. Dietary fat intake and risk of type 2 diabetes in women. Am. J. Clin. Nutr. 2001, 73, 1019-1026. [CrossRef] [PubMed]

45. Kien, C.L. Dietary interventions for metabolic syndrome: Role of modifying dietary fats. Curr. Diabetes Rep. 2009, 9, 43-50. [CrossRef] [PubMed]

46. Haag, M.; Dippenaar, N.G. Dietary fats, fatty acids and insulin resistance: Short review of a multifaceted connection. Med. Sci. Monit.: Int. Med. J. Exp. Clin. Res. 2005, 11, RA359-RA367.

47. Kahleova, H.; Hlozkova, A.; Fleeman, R.; Fletcher, K.; Holubkov, R.; Barnard, N.D. Fat Quantity and Quality, as Part of a Low-Fat, Vegan Diet, Are Associated with Changes in Body Composition, Insulin Resistance, and Insulin Secretion. A 16-Week Randomized Controlled Trial. Nutrients 2019, 11, 615. [CrossRef]

48. Zhao, L.; Zhang, F.; Ding, X.; Wu, G.; Lam, Y.Y.; Wang, X.; Fu, H.; Xue, X.; Lu, C.; Ma, J.; et al. Gut bacteria selectively promoted by dietary fibers alleviate type 2 diabetes. Science 2018, 359, 1151-1156. [CrossRef] [PubMed] 
49. Ebrahimzadeh Leylabadlo, H.; Sanaie, S.; Sadeghpour Heravi, F.; Ahmadian, Z.; Ghotaslou, R. From role of gut microbiota to microbial-based therapies in type 2-diabetes. Infect. Genet. Evol. 2020, 81, 104268. [CrossRef]

50. Makki, K.; Deehan, E.C.; Walter, J.; Bäckhed, F. The Impact of Dietary Fiber on Gut Microbiota in Host Health and Disease. Cell Host Microbe 2018, 23, 705-715. [CrossRef] [PubMed]

51. Davison, K.M.; Temple, N.J. Cereal fiber, fruit fiber, and type 2 diabetes: Explaining the paradox. J. Diabetes Its Complicat. 2018, 32, 240-245. [CrossRef] [PubMed] 